\title{
EFFEKTIFITAS MEDIA AUDIO TERHADAP MEDIA VISUAL UNTUK PENINGKATAN PENGETAHUAN MAHASISWA TENTANG HIV/AIDS DI AMBON
}

\author{
Rita Rena Pudyastuti, Abdul Rivai Saleh Dunggio, Johanna Tomasoa, Sri Eny \\ Setyowati, Kariyadi \\ Maluku Ministry of Health Poltekkes, Maluku, Indonesia \\ Email: ritapudyastuti1968@gmail.com, rivaidunggio2016@gmail.com,tomasoa30oke@ \\ gmail.com, enygus@yahoo.com, panteskaryadi@gmail.com
}

\begin{abstract}
Abstrak
Penyakit AIDS (Acquired Immunodeficiency Syndrome) merupakan suatu syndrome / kumpulan gejala penyakit yang disebabkan oleh Retrovirus yang menyerang sistem kekebalan atau pertahanan tubuh. Dengan rusaknya sistem kekebalan tubuh, maka orang yang terinfeksi mudah diserang penyakit-penyakit lain yang berakibat fatal, yang dikenal dengan infeksi oportunistik. AIDS pada anak pertama kali dilaporkan oleh Oleske, Rubinstein dan Amman pada tahun 1983 di Amerika Serikat. Untuk meningkatkan pengetahuan HIV/AIDS pada mahasiswa peneliti menggunakan media audio visual. Media audio visual gerak adalah media intruksional modern yang sesuai dengan perkembangan zaman (kemajuan ilmu pengetahuan dan teknologi) karena meliputi penglihatan, pendengaran dan gerakan, serta menampilkan unsur gambar yang bergerak.Metode yang digunakan didalam penelitian ini adalah metode Penalitian Qusi eksperimen. Metode yang digunakan didalam penelitian ini adalah metode Penalitian Quasi eksperimen. Pada penelitian ini dilibatkan tiga kelas yang dibandingkan, yaitu kelas B (Audio) dan kelas C (Visual). Populasi dalam penelitian ini adalah mahasiswa Jurusan Keperawatan Politeknik Kesehatan Kemenkes Maluku yang berjumlah 352 orang. Dan sampelnya dalam penelitian ini adalah mahasiswa tingkat I semester I Jurusan Keperawatan Kemankes Maluku. Yang berjumlah 80. Karena pada kelas - kelas tersebut belum pernah memperoleh materi tentang HIV/AIDS. Media Audio dan Visual mempunyai pengaruh yang besar untuk meningkatkan pengatahuan mahasiswa dengan hasil uji t diperoleh thitung= 13,980 > ttabel (2.048) yang berarti H1 diterima. Sehingga dapat disimpulkan bahwa terdapat pengaruh yang signifikan antara hasil belajar siswa sebelum dan sesudah menggunakan media audio dan visual (Video) dalam belajar Materi Penyakit HIV/AIDS. Media Visual mempunyai pengaruh terhadap peningkatan pengetahuan mahaiswa dengan dari hasil uji $\mathrm{t}$ diperoleh $\mathrm{t}_{\text {hitung }}=10,370>\mathrm{t}_{\text {tabel }}$ (2.048) yang berarti $\mathrm{H}_{1}$ diterima. Sehingga dapat disimpulkan bahwa terdapat pengaruh yang signifikan antara hasil belajar siswa sebelum dan sesudah menggunakan media visual (gambar dan hand out) dalam belajar Materi Penyakit HIV/AIDS. Media Audio mempunyai pengaruh untuk meningkatkan pengatahuan mahaiswa dengan hasil uji $\mathrm{t}$ diperoleh $\mathrm{t}_{\text {hitung }}=13,552>\mathrm{t}_{\text {tabel }}(2.048)$ yang berarti $\mathrm{H}_{1}$ diterima. Sehingga
\end{abstract}


Rita Rena Pudyastuti, Abdul Rivai Saleh Dunggio, Johanna Tomasoa, Sri Eny Setyowati, Kariyadi

dapat disimpulkan bahwa terdapat pengaruh yang signifikan antara hasil belajar siswa sebelum dan sesudah menggunakan media audio (tape recorder) dalam belajar Materi Penyakit HIV/AIDS.

Kata Kunci : media audio; media visul; pengetahuan; HIV/AIDS

\begin{abstract}
Disease AIDS (Acquired Immunodeficiency Syndrome) is a syndrome / collection of symptoms caused by Retrovirus that attacks the body's immune system or defense. With the damage to the immune system, the infected person is easily attacked by other diseases that are fatal, known as opportunistic infections. AIDS in children was first reported by Oleske, Rubinstein and Amman in 1983 in the United States. To increase knowledge of HIV/AIDS in students, researchers used audio visual media. Motion audio visual media is a modern instructional media that is in accordance with the times (advances in science and technology) because it includes vision, hearing and movement, and displays moving image elements. The method used in this research is experimental Qusi method. The method used in this research is Quasi Experimental Method. In this study three classes were compared, namely class $B$ (audio) and class $C$ (visual). The population in this study were 352 students of Nursing Department of Health Polytechnic of the Ministry of Health of Maluku. And the sample in this study is the first semester students of the Department of Nursing, Ministry of Health, Maluku. Which amounted to 80. Because in these classes had never obtained material about HIV/AIDS. Audio and Visual media have a great influence to increase student knowledge with the results of the test obtained by $t_{\text {count }}=13,980>t_{\text {table }}(2,048)$ which means that $H_{1}$ is accepted. So it can be concluded that there is a significant influence between student learning outcomes before and after using audio and visual media (Video) in learningMaterial HIV/AIDS. Visual media has an influence on increasing student knowledge with the results of the $t$ test obtained $t_{\text {count }}=10.370>t_{\text {table }}$ (2.048) which means that $H_{1}$ is accepted. So it can be concluded that there is a significant influence between student learning outcomes before and after using visual media (pictures and hand outs) in learningmaterial HIV/AIDS. Audio Media has the effect of increasing student knowledge with the results of the t test obtained by $t_{\text {count }}=13,552>t_{\text {table }}(2,048)$ which means that $H_{1}$ is accepted. So it can be concluded that there is a significant influence between student learning outcomes before and after using audio media (tape recorder) in learningmaterial HIV/AIDS.
\end{abstract}

Keywords: media audio; visul media; knowledge; HIV/AIDS

Received: 2021-10-20; Accepted: 2021-11-05; Published: 2021-11-20 


\section{Pendahuluan}

Setiap tahun di seluruh Asia hampir setengah dari penderita HIV baru adalah anak-anak yang berada pada usia sekolah dan remaja di bawah usia 25 tahun. Sementara dana internasional terbesar kebanyakan selama beberapa dekade terakhir telah digunakan untuk menyediakan obat-obatan anti retrovirus bagi mereka yang telah terinfeksi, generasi baru dari anak-anak yang tumbuh dewasa tanpa pengetahuan yang cukup tentang bagaimana melindungi diri mereka dari HIV.

Penyakit AIDS (Acquired Immunodeficiency Syndrome) merupakan suatu syndrome / kumpulan gejala penyakit yang disebabkan oleh Retrovirus yang menyerang sistem kekebalan atau pertahanan tubuh. Dengan rusaknya sistem kekebalan tubuh, maka orang yang terinfeksi mudah diserang penyakit-penyakit lain yang berakibat fatal, yang dikenal dengan infeksi oportunistik. AIDS pada anak pertama kali dilaporkan oleh Oleske, Rubinstein dan Amman pada tahun 1983 di Amerika Serikat

Epidemi HIV-AIDS merupakan krisis global dan tantangan yang berat bagi pembangunan dan kemajuan social. Banyak Negara-negara miskin yang sangat dipengaruhi epidemic ini ditinjau dari jumlah infeksi dan dampak yang ditimbulkannya. Bagian terbesar orang yang hidup dengan HIV-AIDS (ODHA) adalah orang dewasa muda yang berada di usia kerja dan hampir separuhnya adalah wanita yang akhir-akhir ini terinfeksi lebih cepat dari laki-laki. Konsekuensinya dirasakan perusahaan dan ekonomi nasional. Dalam konteks ini pemerintah mempunyai kewajiban untuk menerapkan ketentuan-ketentuan United Nations Declaration of Comitmen on HIVAIDS tahun 2001 yang mencakup komitmen untuk memperkuat sistem pemeliharaan kesehatan dan memperluas cakupan pengobatan, juga peningkatan program pencegahan.

Harus diingat bahwa belum ada vaksin untuk mencegah HIV-AIDS, dan pengobatannya juga belum ada. Pencegahan sangat tergantung pada kampanye kesadaran masyarakat dan perubahan perilaku individu dalam lingkungan yang mendukung, yang memerlukan waktu dan kesabaran. Karena sudah menjalar ke seluruh sector ekonomi dan seluruh bidang kehidupan social, epidemic HIV-AIDS telah merupakan ancaman bagi pertumbuhan dan pembangunan jangka panjang. Tekanan HIV-AIDS terhadap system kesehatan sangat hebat, Untuk itu dikeluarkannya kebijakan Kemenkes RI dalam penanggulangan HIV AIDS Indonesia dalam Keputusan Presiden Nomor 36 Tahun 1994 tentang pembentukan Komisi Penanggulangan AIDS (KPA) dan KPA Daerah sebagai lembaga pemerintah yang mengkoordinaskan pelaksanaan pengendalian AIDS, dimana pemerintah telah membentuk komisi Penanggulangan AIDS (KPA) di tingkat pusat disusul dengan terbentuknya KPA di beberapa provinsi di Indonesia.

Pencegahan HIV menghadapi tantangan ketika bersentuhan dengan nilai sensitifitas agama dan budaya. Promosi tentang kondom, sebagai salah satu dari banyak pengertian sebagai pencegahan HIV, adalah sensitif, karena banyak guru dan orangtua percaya bahwa dengan distribusi dan promosi tentang kondom secara tidak langsung mendorong orang muda untuk menjadi aktif secara seksual. 
Rita Rena Pudyastuti, Abdul Rivai Saleh Dunggio, Johanna Tomasoa, Sri Eny Setyowati, Kariyadi

Kegiatan pencegahan salah satunya dengan penyuluhan dengan metode ceramah, diskusi dan pemutaran video tentang HIV/AIDS dilakukan dengan tujuan memberikan pengetahuan yang benar tentang pencegahan dan cara penularan HIV/AIDS sedini mungkin pada remaja. Kegiatan ini diharapkan dapat mencegah munculnya perilaku berisiko terkait HIV/AIDS sehingga dapat mengurangi penularan HIV/AIDS dan kasus baru di masyarakat terutama di kalangan remaja. Selanjutnya target dan capaian MDG62012 untuk presentase penduduk 15-24 tahun yang mempunyai pengetahuan komprehensif tentang HIV target 2014 sebesar 95\%, sasaran dan strategis pemerintah tahun 2010-2014 adalah Menurunnya prevalensi HIV pada penduduk usia 15-49 tahun menjadi <0,5\%, meningkatnya persentase penduduk usia 15-24 tahun yang memiliki pengetahuan komprehensif tentang HIV-AIDS dari 65\% menjadi 95\%, meningkatnya jumlah penduduk usia 15 tahun atau lebih yang menerima konseling dan tes HIV dari 300.000 menjadi 700.000, Meningkatnya persentase kabupaten/kota yang melaksanakan pencegahan penularan HIV sesuai pedoman dari 50\% menjadi $100 \%$. Selain itu diharapkan Mahasiswa nantinya bersedia menjadi duta atau menyebarkan informasi ini kepada teman teman sebaya, sehingga dapat menekan penyebaran dan kasus HIV/AIDS dikalangan remaja.

Perkembangan dunia yang sangat pesat dalam hal ilmu pengetahuan dan teknologi membuat persaingan antar negara semakin ketat. Oleh karena itu sumber daya manusia yang handal dan professional sangat diperlukan serta didukung oleh lembaga pendidikan yang handal pula. Lembaga pendidikan yang handal harus bisa menciptakan suasana belajar yang aktif, efektif dan komunikatif. Kewajiban pendidik sebagai pelaku pendidikan adalah mencari solusi yang terbaik dan sesuai dengan kebutuhan peserta didik dalam melakukan kegiatan pembelajaran. Masalah ini tentu harus ada juga faktor lain yang bisa mendukung terciptanya kualitas pembelajaran yang baik, baik itu external maupun internal. Pembelajaran adalah suatu usaha yang disengaja bertujuan dan terkendali agar orang lain belajar atau terjadi perubahan yang relative menetap pada diri orang lain. Usaha ini dilakukan oleh seseorang atau suatu tim yang memiliki kemampuan dan kompetensi dalam merancang dan atau mengembangkan sumber belajar yang diperlukan Dalam hal ini untuk menunjang kegiatan pembelajaran dibutuhkan pula sarana prasarana yang memadai, kalaupun tidak terpenuhi para pendidik harus bisa mencari solusi sehingga pembelajaran dapat berjalan dengan baik.

Politeknik Kesehatan (Poltekkes) Kemenkes Maluku adalah unit pelaksana teknis di lingkungan Kementerian Kesehatan, dipimpin oleh Direktur yang berada di bawah Badan Pemberdayaan Sumber Daya Manusia Kesehatan secara profesional bertanggung jawab kepada kepala Pusdiknakes. Poltekkes Kemenkes Maluku mempunyai tugas melaksanakan pendidikan profesional dalam program Diploma III sesuai peraturan dan program pendidikan D III Keperawatan baik jalur umum ataupun program khusus, D III Gizi, D III Kebidanan, D III Kesehatan Lingkungan dan D III Analys Kesehatan. Ada juga prodi keperawatan yang berlokasi di Kabupaten Maluku Tengah tepatnya Prodi Masohi dan Prodi keperawatan di Kota Tual dan Prodi Kebidanan di Maluku Tenggara Barat tepatnya di Saumlaki. Rumusan masalah dalam penelitian ini adalah "Adakah 
pengaruh media audio visual untuk peningkatan pengetahuan Mahasiswa Keperawatan Poltekkes Maluku tentang HIV/AIDS ? Tujuan dalam penelitian ini adalah untuk mengetahui pengaruh media audio dan media visual untuk peningkatan pengetahuan Mahasiswa Keperawatan Poltekkes Maluku tentang HIV/AIDS.

\section{Metode Penelitian}

Metode yang digunakan didalam penelitian ini adalah metode Penalitian Quasi eksperimen. Penelitian eksperimen merupakan penelitian yang dimaksudkan untuk mengetahui ada tidaknya akibat dari "sesuatu" yang dikenakan pada subjek selidik. Dengan kata lain penelitian eksperimen mencoba meneliti ada tidaknya hubungan sebab akibat. Caranya adalah dengan membandingkan satu atau lebih kelompok eksperimen yang diberi perlakuan dengan satu atau lebih kelompok pembanding yang tidak menerima perlakuan.

Pada penelitian ini dilibatkan dua kelas yang dibandingkan, yaitu kelas B dan Kelas C. Populasi dalam penelitian ini adalah mahasiswa Politeknik Kesehatan Ambon. Dan sampelnya dalam penelitian ini adalah mahasiswa tingkat I semester I Jurusan Keperawatan Kemankes Maluku. Alasannya pengambilan sampel ini karena Tingkat I tersebut belum pernah mendapatkan materi perkuliahan tentang HIV/AIDS.

Penelitian ini dilaksanakan di Jurusan Keperawatan Ambon yang beralamat di Jl. Laksda Leo Wattimena Waiheru Ambon. Penelitian diawali dengan survey pendahuluan dan selanjutnya pengurusan ijin penelitian. Dan pelaksanaan penelitian ini dikerjakan tiga bulan yaitu dari bulan september sapai November.

Populasi adalah keseluruhan subjek penelitian (Arikunto, 2005). Subjek penelitian ini adalah mahasiswa Jurusan Keperawatan Kemenkes Maluku, yang ditetapkan secara purposive dengan criteria bersedia mengikuti perlakuan, pada waktu penelitian mahasiswa tersebut belum pernah mendapat materi perkuliahan tentang HIV/AIDS dan belum pernah diberikan metode pengajaran dengan Media Visual dan media Audio tentang materi HIV/AIDS selama kuliah di Poltekkes.

Sampel adalah sebagian atau wakil populasi yang diteliti (Arikunto, 2005). Sampel dari penelitian ini adalah mahasiswa tingkat I semester I yang berjumlah 80 siswa. Namun dalam penelitian ini kelas B yang berjumlah 40 orang sebagai kelas perlakuan Media Visual dan kelas $\mathrm{C}$ yang berjumlah 40 orang dengan perlakuan Media Audio.

\section{Pemabahasan}

Pada penelitian ini, peneliti mengambil subyek penelitian pada mahasiswa Poltekkes Jurusan Keperawatan Ambon. Mahasiswa yang menjadi sampel ialah mahasiswa tingkat I semester sebagaimana telah diungkap sebelumnya, pada penelitian ini menggunakan dua kelas yaitu kelas B dan kelas C. Sebelum dilakukan pembelajaran peneliti memberi tes awal (pretest) kepada kelas B dan kelas $\mathrm{C}$ dan setelah dilakukan perlakuan baru diadakan post test, dengan soal yang sama. 
Rita Rena Pudyastuti, Abdul Rivai Saleh Dunggio, Johanna Tomasoa, Sri Eny Setyowati, Kariyadi

Tabel 1

Daftar Mahasiswa

\begin{tabular}{rrccc}
\hline \multicolumn{1}{c}{ No } & Kelas & Laki-laki & Perempuan & Jumlah \\
\hline 1 & Kelas B & 10 & 30 & 40 \\
\hline 2 & Kelas C & 11 & 29 & 40 \\
\hline & & 31 & 59 & 80 \\
\hline
\end{tabular}

Pada tabel 1 dapat di jelaskan bahwa jumlah subjek penelitian adalah 80 orang, terdiri dari jumlah mahasiswa laki-laki adalah 31 orang dan jumlah mahasiswa perempuan adalah 59 orang. Jadi jumlah mahasiswa perempuan lebih banyak dari lakilaki. Berikut ini adalah tabel frekuensi Pre Test Visual Kelas B:

Tabel 2

Tabel Frekuensi skor Pre test Visual Kelas B

\begin{tabular}{|c|c|c|c|c|}
\hline Skor & Jumlah & $\%$ & Valid \% & Kumulative \% \\
\hline 8 & 1 & 2,5 & 2,5 & 2,5 \\
\hline 9 & 2 & 5,0 & 5,0 & 7,5 \\
\hline 10 & 2 & 5,0 & 5,0 & 12,5 \\
\hline 11 & 4 & 10,0 & 10,0 & 22,5 \\
\hline 12 & 4 & 10,0 & 10,0 & 32,5 \\
\hline 13 & 10 & 25,0 & 25,0 & 57,5 \\
\hline 14 & 7 & 17,5 & 17,5 & 75,0 \\
\hline 15 & 7 & 17,5 & 17,5 & 92,5 \\
\hline 16 & 2 & 5,0 & 5,0 & 97,5 \\
\hline 18 & 1 & 2,5 & 2,5 & 100,0 \\
\hline Total & 40 & 100,0 & 100,0 & \\
\hline
\end{tabular}

Tabel 2 menunjukkan bahwa jumlah frekuansi skor nilai pre test visual terbanyak yaitu ada 10 orang dan frekuansi skor nilai post test visual terkecil 2 orang yaitu 1 orang skor tertinggi dan 1 orang skor terrendah. Jadi frekuansi skor nilai posttest visual terbanyak yaitu skor 10 dengan persentasinya adalah $25 \%$.

Berikut ini adalah penyajian tabel data frekuensi Post Test Visual Kelas B :

Tabel 3

Tabel Frekuensi skor Post test Visual Kelas B

\begin{tabular}{|c|c|c|c|c|}
\hline Skor & Jml & $\%$ & Valid \% & Kumulative \% \\
\hline 12 & 1 & 2,5 & 2,5 & 2,5 \\
\hline 14 & 3 & 7,5 & 7,5 & 10,0 \\
\hline 15 & 8 & 20,0 & 20,0 & 30,0 \\
\hline 16 & 4 & 10,0 & 10,0 & 40,0 \\
\hline 17 & 8 & 20,0 & 20,0 & 60,0 \\
\hline 19 & 8 & 20,0 & 20,0 & 80,0 \\
\hline 20 & 6 & 15,0 & 15,0 & 95,0 \\
\hline 21 & 1 & 2,5 & 2,5 & 97,5 \\
\hline
\end{tabular}


Effektifitas Media Audio terhadap Media Visual untuk Peningkatan Pengetahuan Mahasiswa Tentang HIV/AIDS di Ambon

\begin{tabular}{lrrrr}
\hline 23 & 1 & 2,5 & 2,5 & 100,0 \\
\hline Total & 40 & 100,0 & 100,0 & \\
\hline
\end{tabular}

Tabel 3 menunjukkan bahwa jumlah frekuansi skor nilai post test visual terbanyak yaitu ada 8 orang yaitu ada 3 kategori dan frekuansi skor nilai post test visual terkecil 3 orang yaitu 3 kategori. Jadi frekuansi skor nilai posttest visual terbanyak adalah 15,16 dan 19 yaitu $20 \%$. Berikut ini adalah penyajian tabel data frekuensi Pre Test Audio Kelas C:

Tabel 4

Tabel Frekuensi skor Pre Test Audio Kelas C

\begin{tabular}{crrrr}
\hline Skor & Jumlah & \multicolumn{1}{c}{$\%$} & Valid \% & Cumulative $\%$ \\
\hline 8 & 1 & 2,5 & 2,5 & 2,5 \\
\hline 9 & 2 & 5,0 & 5,0 & 7,5 \\
\hline 10 & 5 & 12,5 & 12,5 & 20,0 \\
\hline 11 & 6 & 15,0 & 15,0 & 35,0 \\
\hline 12 & 2 & 5,0 & 5,0 & 40,0 \\
\hline 13 & 7 & 17,5 & 17,5 & 57,5 \\
\hline 14 & 3 & 7,5 & 7,5 & 65,0 \\
\hline 15 & 9 & 22,5 & 22,5 & 87,5 \\
\hline 16 & 4 & 10,0 & 10,0 & 97,5 \\
\hline 17 & 1 & 2,5 & 2,5 & 100,0 \\
\hline Total & 40 & 100,0 & 100,0 & \\
\hline
\end{tabular}

Tabel 4 menunjukkan bahwa jumlah frekuansi skor nilai post test visual terbanyak yaitu ada 9 orang dan frekuansi skor nilai post test visual terkecil 2 orang yaitu 2 kategori. Jadi frekuansi skor nilai posttest visual terbanyak adalah 15, dengan persentasi 22,5\%. Berikut ini adalah penyajian tabel data frekuensi skor Post Test Audio Kelas C :

Tabel 5

Tabel Frekuensi skor Post Test Audio Kelas C

\begin{tabular}{|c|c|c|c|c|}
\hline Skor & $\mathrm{Jml}$ & $\%$ & Valid \% & Cumulative \% \\
\hline 11 & 1 & 2,5 & 2,5 & 2,5 \\
\hline 12 & 1 & 2,5 & 2,5 & 5,0 \\
\hline 14 & 1 & 2,5 & 2,5 & 7,5 \\
\hline 15 & 6 & 15,0 & 15,0 & 22,5 \\
\hline 16 & 3 & 7,5 & 7,5 & 30,0 \\
\hline 17 & 4 & 10,0 & 10,0 & 40,0 \\
\hline 18 & 8 & 20,0 & 20,0 & 60,0 \\
\hline 19 & 10 & 25,0 & 25,0 & 85,0 \\
\hline 20 & 5 & 12,5 & 12,5 & 97,5 \\
\hline 21 & 1 & 2,5 & 2,5 & 100,0 \\
\hline Total & 40 & 100,0 & 100,0 & \\
\hline
\end{tabular}


Rita Rena Pudyastuti, Abdul Rivai Saleh Dunggio, Johanna Tomasoa, Sri Eny Setyowati, Kariyadi

Tabel 5 menunjukkan bahwa jumlah frekuansi skor nilai post test audio terbanyak yaitu ada 10 orang dan frekuansi skor nilai post test audio terkecil 4 orang yaitu 4 kategori. Jadi frekuansi skor nilai posttest audio visual terbanyak adalah skor 19, dengan persentasi $25 \%$.

Hasil Uji Statistik Uji t Uji Pretest - Postest Kelas B (Visual)

Tabel 6

Paired Samples Statistik

Mean N Std. Deviation Std. Error Mean

\begin{tabular}{llllll}
\multirow{2}{*}{ Pair 1 } & Previsual kelas B & 13,03 & 40 & 2,106 &, 333 \\
\cline { 2 - 6 } & Postvisual kelas B & 17,25 & 40 & 2,394 &, 379 \\
\hline
\end{tabular}

Perbedaan mean menunjukkan bahwa postest kelas B (Visual) tentang Materi Penyakit HIV/AIDS lebih baik dibandingkan dengan pretest.

Tabel 7

Paired Samples Test

Paired Samples Test

\begin{tabular}{|c|c|c|c|c|c|c|c|c|c|}
\hline \multicolumn{10}{|c|}{ Paired Samples Test } \\
\hline & & \multicolumn{5}{|c|}{ Paired Differences } & \multirow[t]{3}{*}{$\mathrm{t}$} & \multirow[t]{3}{*}{$\mathrm{df}$} & \multirow{3}{*}{$\begin{array}{l}\text { Sig. } \\
(2- \\
\text { taile } \\
\text { d) }\end{array}$} \\
\hline & & \multirow[t]{2}{*}{ Mean } & \multirow[t]{2}{*}{$\begin{array}{c}\text { Std. } \\
\text { Deviation }\end{array}$} & \multirow[t]{2}{*}{$\begin{array}{l}\text { Std. } \\
\text { Error } \\
\text { Mean }\end{array}$} & \multicolumn{2}{|c|}{$\begin{array}{c}95 \% \\
\text { Confidence } \\
\text { Interval of } \\
\text { the } \\
\text { Difference } \\
\end{array}$} & & & \\
\hline & & & & & $\begin{array}{c}\text { Low } \\
\text { er }\end{array}$ & $\begin{array}{l}\text { Upp } \\
\text { er }\end{array}$ & & & \\
\hline $\begin{array}{l}\text { Pair } \\
1\end{array}$ & $\begin{array}{l}\text { Previsual } \\
\text { kelas B - } \\
\text { Postvisual } \\
\text { kelas B }\end{array}$ & $\begin{array}{r}- \\
4,22 \\
5\end{array}$ & 2,577 & ,407 & $\begin{array}{r}- \\
5,04 \\
9\end{array}$ & $\begin{array}{l}- \\
3,40 \\
1\end{array}$ & $\begin{array}{r}- \\
10 \\
, 3 \\
70\end{array}$ & 39 &, 000 \\
\hline
\end{tabular}

Berdasarkan uji statistik pada tabel di atas menunjukkan bahwa hasil pre test dan postest kelas B (Visual) Penyakit HIV/AIDS adalah sebagai berikut: Output menampilkan mean pretest dan postest kelas B (Visual) adalah -4,225, standar deviasi 2,577 dan mean standar errornya 0,407. Perbedaan terendah keduanya $-5,049$ sementara perbedaan tertinggi $-3,401$. Hasil uji tes $\mathrm{t}=-10,370$ dengan $\mathrm{df}=59$ dan signifikansi 0,000. Berdasarkan t tabel untuk $\mathrm{df}=59$ diperoleh angka 2,04 untuk taraf signifikan 5\% dan 2,76 untuk taraf signifikan $1 \%$. Dengan $\mathrm{t} 0=-10,370$ berarti lebih besar dari $\mathrm{tt}$ (tanda matematik minus dalam hal ini diabaikan) pada taraf signifikansi 5\% maupun taraf signifikansi $1 \%(2,04<10,370$ yang berarti hipotesis nihil ditolak. Kesimpulannya terdapat perbedaan yang signifikan antara pretest dan postest siswa kelas B (Visual) tentang Penyakit HIV/AIDS. Sedangkan perbedaan mean menunjukkan bahwa postest 
kelas B (Eksperimen) tentang Konsep dasar Promosi Kesehatan lebih baik dibandingkan dengan pretest.

Hasil Uji Statistik Uji t Kelas C

\section{Tabel 8}

Paired Samples Statistics Pre and Post Audio

\begin{tabular}{llllrr}
\hline & Mean & N & Std. Deviation & \multicolumn{2}{c}{$\begin{array}{c}\text { Std. Error } \\
\text { Mean }\end{array}$} \\
\hline Pair & Preaudio kelas C & 12,88 & 40 & 2,366 &, 374 \\
\cline { 2 - 6 } 1 & Postaudio kelas C & 17,45 & 40 & 2,253 &, 356 \\
\hline
\end{tabular}

Perbedaan mean menunjukkan bahwa postest kelas $\mathrm{C}$ (Audio) tentang Materi Penyakit HIV/AIDS lebih baik dibandingkan dengan pretest. Yaitu Pretest Mean 12,88 dan Post test mean 17,45. Dengan Standar devasi 2,366 untuk pretest dan 2,253 untuk Postest Kelas C.

Tabel 9

Paired Samples Test Pre and Post Audio

\begin{tabular}{|c|c|c|c|c|c|c|c|c|c|}
\hline & & \multicolumn{5}{|c|}{ Paired Differences } & \multirow[t]{3}{*}{$\mathrm{t}$} & \multirow{3}{*}{$\begin{array}{l}d \\
f\end{array}$} & \multirow{3}{*}{$\begin{array}{l}\text { Sig. } \\
(2- \\
\text { taile } \\
\text { d) }\end{array}$} \\
\hline & & \multirow[t]{2}{*}{ Mean } & \multirow[t]{2}{*}{$\begin{array}{l}\text { Std. } \\
\text { Deviati } \\
\text { on }\end{array}$} & \multirow[t]{2}{*}{$\begin{array}{l}\text { Std. } \\
\text { Error } \\
\text { Mean }\end{array}$} & \multicolumn{2}{|c|}{$\begin{array}{l}95 \% \text { Confidence } \\
\text { Interval of the } \\
\text { Difference }\end{array}$} & & & \\
\hline & & & & & Lower & Upper & & & \\
\hline $\begin{array}{l}\text { Pair } \\
1\end{array}$ & $\begin{array}{l}\text { Preaudi } \\
\text { o kelas } \\
\text { C - } \\
\text { Postaud } \\
\text { io kelas } \\
\text { C }\end{array}$ & $\begin{array}{r}4,57 \\
5\end{array}$ & 2,135 & ,338 & $-5,258$ & $-3,892$ & $\begin{array}{r}- \\
1 \\
3, \\
5 \\
5 \\
2\end{array}$ & $\begin{array}{l}3 \\
9\end{array}$ &, 000 \\
\hline
\end{tabular}

Berdasarkan uji statistik pada tabel di atas menunjukkan bahwa hasil pre test dan postest kelas C (Audio) Materi Penyakit HIV/AIDS adalah sebagai berikut: Output menampilkan mean pretest dan postest kelas C (Audio) adalah -4,575, standar deviasi 2,135 dan mean standar errornya 0,338 . Perbedaan terendah keduanya $-5,258$ sementara perbedaan tertinggi $-3,892$. Hasil uji tes $\mathrm{t}=-13,552$ dengan $\mathrm{df}=59$ dan signifikansi 0,000. Berdasarkan t tabel untuk $\mathrm{df}=59$ diperoleh angka 2,04 untuk taraf signifikan 5\% dan 2,76 untuk taraf signifikan $1 \%$. Dengan t0 $=-13,552$ berarti lebih besar dari $t$ (tanda matematik minus dalam hal ini diabaikan) pada taraf signifikansi 5\% maupun taraf signifikansi $1 \%(2,04<13,522$ yang berarti hipotesis nihil ditolak. Kesimpulannya terdapat perbedaan yang signifikan antara pretest dan postest siswa kelas C (Audio) tentang Penyakit HIV/AIDS. Sedangkan perbedaan mean menunjukkan bahwa postest kelas $\mathrm{C}$ tentang Materi Penyakit HIV/AIDS lebih baik dibandingkan dengan pretest.

Penelitian ini merupakan, penelitian eksperimen untuk melihat dan membandingkan hasil belajar mahasiswa Poltekkes, khsususnya jurusan Keperawatan 
Rita Rena Pudyastuti, Abdul Rivai Saleh Dunggio, Johanna Tomasoa, Sri Eny Setyowati, Kariyadi

Tingkat I dengan menggunakan media visual terhadap peningkatan pengetahuan pada pretest dan postest terhadap mahasiswa dalam mempelajari materi Penyakit HIV/AID. Media Visual yang digunakan dalam penelitian ini adalah : media Gambar dan tulisan (hand out). Media gambar adalah merupakan alat bantu yang dapat digunakan untuk menghantarkan ataupun menyampaikan pesan, berupa segala pengetahuan serta memiliki pesan-pesan dan makna yang disampaikan. Secara umum manfaat media gambar Tentang penyakit HIV/AIDS sebagai alat bantu untuk mewujudkan situasi kemajuan yang efektif, bagian integral dari keseluruhan mengajar, meletakkan dasardasar yang kuat dan konsep yang abstrak sehingga dapat mempunyai pemahaman yang bersifat verbalisme., membangkitkan motivasibelajar siswam mempertinggi hasil dan mutu belajar mengajar, motivasi belajar siswa lebih aktif dalam proses pembelajaran ini, hal ini disebabkan dengan adanya penggunaan media gambar yang membuat mahasiswa lebih bersemangat dalam belajar, Keaktifan mahasiswa lebih meningkat dimana mahasiswa merasa lebih diaktifkan dalam belajar, bukan dosen saja yang aktif dalam pembelajaran ini. Akan tetapi mahasiswa yang sedang belajar menyadari bahwa tujuan yang hendak dicapai dan bermanfaat bagi dirinya sendiri, motivasi mahasiswa dengan sendirinya muncul kuat dalam dirinya, yang ingin menguasai kemampuan yang terkandung dalam tujuan pembelajaran yang bermanfaat untuk dirinya, sehingga menghasilkan pemahaman materi Penyakit HIV/AIDS lebih mendalam, kritis dan kreatif sehingga skor yang dicapai mahasiswa antar pretest dan posttest ada perbedaan yang signifikan. ini. Hal ini juga sesuai dengan Copper (2010) tentang Aktivitas belajar siswa dapat digolongkan dalam beberapa hal yaitu : 1). Aktivitas Visual (visual activites) seperti membaca, menulis, melakukan eksperimen dan demonstarsi. 2) Aktivitas lisan (oral activitas) seperti bercerita, membaca sajak, tanya jawab, diskusi dan menyanyi. 3) Aktivitas mendengarkan (listening activites) seperti mendengarkan penjelasan guru, ceramah dan pengarahan. 4) Aktivitas gerak (motor activities) seperti senam, akletik menari dan melukis. 5) Aktivitas menulis (writing activites) seperti mengarang membuat makalah dan membuat surat.

Dalam hal ini mahasiswa dapat lebih mudah memahami suatu peristiwa ketika mereka menyaksikan secara visual suatu rangkain peristiwa tersebut. Penggunaan media visual dinilai akan lebih mempermudah mahasiswa mengetahui dan mengigat kejadian demi kejadian. Hal ini dikarenakan mahasiswa lebih mudah merekam kejadian yang mereka lihat dibandingkan kejadian yang hanya diceritakan secara verbal. Dari penelitian ini dapat diketahui bahwa siswa lebih mudah memahami suatu peristiwa yang dilihatnya secara visual dan bisa menyebutkan proses apa yang terjadi didalamnya. Hal ini berbeda ketika guru menanyakan suatu pertanyaan hanya dengan cara verbal. Dengan demikian dapat diketahui bahwa penggunaan media visual yaitu dengan menggunakan gambar pembelajaran akan mempermudah siswa dalam memahami suatu peristiwa-peristiwa yang mereka lihat.

Kondisi belajar mengajar yang efektif adalah minat dan perhatian siswa dalam belajar, Uzer (2011) mengemukakan bahwa "minat ini besar sekali pengaruhnya terhadap belajar sebab dengan minat sesorang akan melakukan sesuatu yang 
diminatinya, sebaliknya tanpa minat seseorang tidak mungkin melakukan sesuatu". Keterlibatan siswa dalam belajar erat kaitanya dengan sifat-sifat murid, baikyang bersifat kognitif seperti kecerdasan dan bakat. Maupun yang bersifat keaktifan, rasa percaya diri dan minatnya. Minat dalam arti motif adalah daya dalam diri seseorang yang mendoronya untuk melakukan sesuatu, atau keadaan seseorang atauorganisme yang menyebabkan kesiapanya untuk memakai serangkaian tingkah lakuatau perbuatan. Sedangkan keaktifan adalah suatu proses untuk mengiatkan motif- motif menjadi perbuatan atau tingkah laku untuk memenuhi kebutuhan dan mencapai tujuan atau keadaan atau kesiapan dalam diri individu yang mendorong tingkah lakunya untuk berbuat sesuatu dalam mencapai tujuan tertentu. Tugas dosen adalah membangkitkan keaktifan mahasiswa sehingga ada keinginanya untuk belajar. Dengan demikian media Visual juga dapat meningkatkan pengetahuan mahaiswa. Ini dapat dibuktikan skor pretest dan post test ada perbedaan yang berarti, jadi media Visual dapat mempengaruhi peningkatan pengetahuan mahasiswa dalam mempelajari Penyakit HIV/AIDS.

Adanya pengaruh media audio terhadap peningkatan pengetahuan pada pretest dan postest terhadap mahasiswa dalam mempelajari materi Penyakit HIV/AIDS. Media audio yaitu media yang berkaitan dengan indera pendengaran. Pesan yang akan disampaikan dituangkan dalam lambang-lambang auditif, baik verbal (kedalam katakata/bahasa lisan) maupun non verbal. Beberapa jenis media yang termasuk dalam kelompok ini adalah radio, dan alat perekam pita magnetic. Dalam penelitian ini peneliti menggunakan media tape recorder dan speaker. Karena hal ini terlihat ketika banyak yang asyik sendiri, mengantuk, keluar masuk kelas dengan berbagai alasan, bermain bahkan yang mahasiswi ada yang berdandan, meskipun sudah ditegur. Pada saat pembelajaran berlangsung hanya sedikit mahasiswa yang mau menjawab pertanyaan yang diajukan Dosen dan tidak ada mahasiswa yang mengajukan pertanyaan ketika diberikan kesempatan untuk bertanya. Hal ini dikarenakan para mahasiswa belum terbiasa aktif bertanya didalam kelas, penyebabnya bisa berasal dari siswa itu sendiri atau bisa juga dikarenakan metode mengajar guru selama ini yang tidak mengarahkan siswa untuk lebih aktif dalam pembelajaran.

Ketika dosen menyampaikan pertanyaan, tidak terlihat mahasiswa berusaha mencari jawaban atas pertanyaan tersebut. Hal ini disebabkan mahasiswa tidak memiliki buku atau sumber belajar lain, jawaban siswa hanya berdasarkan perkiraan saja, sehingga siswa tidak terlihat termotivasi ketika mengikuti pelajaran dan dari hasil pre test juga masih banyak yang mendapat skor dibawah standar. Sedangkan dengan menggunakan media audio pada saat pembelajaran peneliti menampilkan cuplikan cerita yang berkaitan dengan materi Penyakit HIV/AIDS. Ketika tape recorder diperdengarkan, mahasiswa sempat ada yang tersenyum dan tertawa, tetapi kemudian lebih fokus memperhatikan materi didalam audio tersebut. Terkadang materi dari mata kuliah yang disampaikan hanya sekedar dipelajari didalam kelas dengan cakupan yang belum luas, sehingga pesan moral yang terkandung pada mata kuliah kurang tersampaikan. hal ini dikarenakan keterbatasan alokasi waktu pelajaran itu sendiri. Cakupan materi juga bisa lebih luas apabila menggunakan 
Rita Rena Pudyastuti, Abdul Rivai Saleh Dunggio, Johanna Tomasoa, Sri Eny Setyowati, Kariyadi

audio pembelajaran. Karena audio pembelajaran tidak hanya menampilkan pengertian tetapi dengan contoh-contoh yang terdapat pada materi pelajaran saja pelajaran yang mereka dapatkah akan lebih mendalam dan menjadi pengalaman mereka dalam kehidupan sehari-hari.

\section{Kesimpulan}

Berdasarkan hasil penelitian menggunakan kuasi ekperimen dapat diambil kesimpulan bahwa Media Visual mempunyai pengaruh terhadap peningkatanpengetahuan mahaiswa. Hal ini di buktikan dari hasil uji t diperoleh $t_{\text {hitung }}=$ $10,370>t_{\text {tabel }}(2.048)$ yang berarti $\mathrm{H}_{1}$ diterima. Sehingga dapat disimpulkan bahwa terdapat pengaruh yang signifikan antara hasil belajar siswa sebelum dan sesudah menggunakan media visual (gambar dan hand out) dalam belajar Materi Penyakit HIV/AIDS.

Media Audio mempunyai pengaruh untuk meningkatkan pengatahuan mahaiswa. Hal ini di buktikan dari hasil uji $t$ diperoleh $t_{\text {hitung }}=13,552>t_{\text {tabel }}(2.048)$ yang berarti $\mathrm{H}_{1}$ diterima. Sehingga dapat disimpulkan bahwa terdapat pengaruh yang signifikan antara hasil belajar siswa sebelum dan sesudah menggunakan media audio (tape recorder) dalam belajar Materi Penyakit HIV/AIDS.

\section{BIBLIOGRAPHY}

Achmad, Arief. (2004). Pemanfaatan Media Massa Sebagai Sumber Pembelajaran IPS di Tingkat Persekolahan.(online. http://hsc.csu.edu.au/pta/scansw/bias.htm, diakses, 12 Febuari 2015). 
Achmad Sugandi, dkk. (2006). Teori Pembelajaran. Semarang : UNNES PRESS.

Azhar Arsad (2005). media pembelajaran (online) (http://ebookbrowse.com/download buku-media-pembelajaran-azhar-arsya.diakses, 17 Mei 2015

Arikunto, S. (2005). Manajemen penelitian.

FKIP Untan. (2007). Pedoman Penulisan Karya Ilmiah Fakultas Keguruan dan Ilmu Pendidikan. Pontianak: FKIP Universitas Tanjungpura.

Hadari Nawawi. (1990). Metode penelitian bidang sosial : Gajahmada University Press.

Hamalik, Oemar. (1994). Kurikulum Dan Pembelajaran. Bandung : PT Bumi ASARA.

Hamdani Strategi Belajar Mengajar (online) ( http//:buku-rahma.blogspot.com, di akses, April 2015 )

Heri."AsuhanKeperawatanHIV/AIDS",(Online),(http://mydocumentku.blogspot.com/20 12/03/asuhan-keperawatan-hivaids.html, diakses 20 Oktober 2015).

Istiqomah, Endah."Asuhan Keperawatan pada Kliendengan HIV/AIDS",(Online) (http://ndandahndutz.blogspot.com/2009/07/asuhan-keperawatan-pada-kliendengan.html, diakses 20 Oktober 2015).

Price, Sylvia A dan Lorraine M.Wilson.2005. Patofissiologis Konsep Klinis Proses Proses Penyakit .Jakarta : EGC

Slameto (2003). Belajar dan Faktor- Faktor yang Mempengaruhi. Jakarta: Rineka Cipta. Sudjana. (2002). Metode statistika. Bandung: Tarsito.

Soekidjo, Notoadmodjo. (2002). Metodologi Penelitian Kesehatan. Jakarta : PT Rineka Cipta

Suharsimi Arikunto. (2006). Prosedur Penelitian Suatu Pendekatan Praktik. Jakarta: Rineka Cipta.

Sugiono. Metode Penelitian Pendidikan: (online) (http://sutama.files.wordpress.com di akses, 4 Agustus 2015.)

Soekidjo, Notoadmodjo. (2002). Metodologi Penelitian Kesehatan. Jakarta : PT Rineka Cipta

Trianto (2009) Mendesain Model Pembelajaran Inovatif progresif. Jakarta: Kencana.

Uzer (2011). Kondisi belajar mengajar yang efektif adalah minat dan perhatian siswa dalam belajar http://mydocumentku.blogspot.com/2015

\section{Copyright holder:}

Rita Rena Pudyastuti, Abdul Rivai Saleh Dunggio, Johanna Tomasoa, Sri Eny

Setyowati, Kariyadi (2021)

First publication right:

Syntax Literate: Jurnal Ilmiah Indonesia

This article is licensed under:

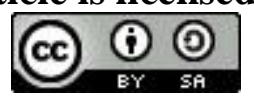

